\title{
Narratives of Force: The Presence of the Writer in International Legal Scholarship
}

\author{
Lianne J. M. Boer ${ }^{1,2}$ \\ Published online: 24 April 2019 \\ (c) The Author(s) 2019
}

\begin{abstract}
In this article I use the notion of 'plot' to uncover where in their texts international legal scholars are 'present', directing readers toward a particular conclusion about the meaning of law. I use Peter Brooks' Reading for the Plot, in which he understands plot as 'the design and intention of narrative, what shapes a story and gives it a certain direction or intent of meaning' (p. xi). In short, Brooks is concerned with plot as the movement caused by the order in which events are presented, making sure the reader continues reading. Drawing on the debate on cyberattacks and international law, my aim is to show where in these scholarly texts plot decisions are made by its writers and how these affect the conclusions drawn by them about the meaning of law. In order to show what I mean by the 'presence of the writer' I start with an analysis of metadiscourse: those elements of a text by means of which writers explicitly 'manifest' (Hyland) themselves, such as 'in this section I will argue'. The discussion of metatext will hopefully then help to explain what I mean by plot as similar-though perhaps less obvious_-proof of the writer's presence. Overall, my aim is to show where restrictions on our reading experience-the boundaries of what is and is not law-are imposed by the writer.
\end{abstract}

Keywords Plot - Metadiscourse - International legal scholarship · Cyberattacks · Use of force

Lianne J. M. Boer

1.j.m.boer@vu.nl

1 Assistant Professor of Transnational Legal Studies, Vrije Universiteit Amsterdam, Amsterdam, The Netherlands

2 Research Fellow of the Centre for the Politics of Transnational Law, Amsterdam, The Netherlands 


\section{Introduction}

In 2000, Thomas C. Wingfield published a book entitled The Law of Information Conflict: National Security Law in Cyberspace. ${ }^{1}$ Legal writing on the application of international law to war in cyberspace had only just started to emerge, and Wingfield was one of a group of predominantly US scholars already concerned with this new form of warfare. 'Advances in computer technology and networking', he wrote, 'will revolutionize future warfare as well as reshape the rule of law and traditional notions of sovereignty'. ${ }^{2}$ The aim of his book, therefore, was 'to serve as a modest beginning to the task of providing a detailed analysis of the law of information conflict'. ${ }^{3}$

Part of this analysis pertains to Article 2(4) of the UN Charter, the prohibition on the use of force. In his sixth chapter, entitled 'Application of Existing Rules', Wingfield attempts to reconstruct the meaning of the prohibition so as to see whether it can feasibly serve to regulate cyberattacks. He states that this attempt is however somewhat hampered by the absence of actual examples of the kind of information conflict envisaged: he writes how 'there are no reported information operations in cyberspace that will exemplify these principles' ${ }^{4}$ So instead he resorts to 'somewhat simplified hypothetical scenarios [...] to demonstrate how [the] jus ad bellum may restrict state activities in cyberspace, ${ }^{5}$ One of these stories reads as follows:

State B completely jams all electronic transmissions into, out of, and within State A. This has a devastating effect on State A [...] Emergency services are significantly curtailed throughout State A, and the flow of emergency medical data between hospitals has stopped. No financial transaction can occur electronically within State A or between anyone in State A and someone in another state. The volume of imports and exports has dropped sharply $95 \%$ from the previous month $[\ldots]$ Without a single shot being fired, State A has effectively been brought to its knees in a few short months and is at the complete mercy of State B. ${ }^{6}$

Wingfield concludes this scenario with the claim that 'State B's virtual blockade of State A is a use of force within the meaning of Article 2(4)'. ${ }^{7}$

The kind of storytelling as done here by Wingfield is not particular to the debate on cyberattacks, but its context is very specific. Back in 2000, legal scholars could draw on very little (if any) actual examples of the kinds of cyberattacks they were

\footnotetext{
1 Wingfield (2000).

${ }^{2}$ Wingfield (2000), p. xvi.

${ }^{3}$ Wingfield (2000), p. xvi.

${ }^{4}$ Wingfield (2000), p. 91 , fn. 235.

5 Wingfield (2000), p. 91, fn. 235.

${ }^{6}$ Wingfield (2000), pp. 91-92. The remainder of his sixth chapter is similarly filled with these kinds of scenarios.

7 Wingfield (2000), p. 92.
} 
concerned with when considering the application of rules such as Article 2(4). ${ }^{8}$ Writing around the same time, another major contributor to the debate-Michael Schmitt—similarly stated how '[h]ypothetical examples of [computer network attacks], some realistic, others stretching credulity, abound in the literature'. ${ }^{9}$ This changed only recently with the emergence of real-world cyberattacks: writing in 2014, Marco Benatar stated how '[t]he rise in the number of serious cyber incidents in recent years, once confined to science fiction lore, has led various writers to take such attacks as the point of departure for their scientific inquiries'. ${ }^{10}$

So, Thomas Wingfield refers to 'scenarios', Marco Benatar to 'science fiction lore' and Michael Schmitt to 'hypothetical examples stretching credulity'. In other words, in this debate storytelling is used as a 'structured attempt to imagine [...] what cyberwar might, could, or ought to look like from the perspective of international law'. ${ }^{11}$ Whether these stories are 'hypothetical account[s]' or the 'retellings of actual events', ${ }^{12}$ we can identify them as serving a particular purpose in legal argumentation: as illustrations, examples or (in the words of Wingfield) 'a superb way to demonstrate' how law operates 'in practice'. ${ }^{13}$

But to view these hypotheticals or retellings as stories does raise the question of which other 'stories' are told in legal scholarship. There is no reason to reduce the notion of narrative to that which we 'intuitively recognize' ${ }^{14}$ as such. As Jane Baron and Julia Epstein point out, legal scholarship itself might similarly be regarded as narrative. ${ }^{15}$ Articles in journals, book chapters, posts on well-known blogs such as Opinio Juris or EJIL Talk!, after all, are also 'stories about what the law is or could be'. ${ }^{16}$ In this view, 'narrative' refers to more than just the scenarios or examples that illustrate what cyberwar might look like, or the rendition of cyberattacks that have 'actually' happened. The attempts by scholars such as Thomas Wingfield to interpret a norm in order to facilitate its application to cyberattacks are also narratives about the meaning of law.

To consider international legal scholarship as 'stories about what the law is' changes the questions we ask of the texts we read. From a doctrinal point of view an article about cyberattacks and Article 2(4) may offer a more or less persuasive interpretation of the prohibition on the use of force. For example, we may be convinced

\footnotetext{
${ }^{8}$ It would be going too far to outline the different definitions circulating in this debate, particularly in the early days, on what constitutes a cyberattack, information operations or information warfare (to name a few terms). Suffice it to say that the perceived need to resort to hypotheticals depends on how one conceptualizes these terms. Richard Aldrich, for example, wrote a piece in 2000 in which he discussed an attempted attack on the US during the 1991 Gulf War-an attack he qualified as an 'information attack'. See Aldrich (1999), pp. 227-228.

9 Schmitt (1999), p. 892.

10 Benatar (2014), 'Case Studies'; see also Foltz (2012), pp. 40-41 and Boer (2017), pp. 40-41.

11 Werner and Boer (2017), p. 40. We state this specifically in relation to the Tallinn Manual.

12 Baron and Epstein (1997), p. 180.

13 Wingfield (2000), p. 91, fn. 235. Baron and Epstein similarly point out that these overt stories purport to 'provide evidence of an important fact'. Baron and Epstein (1997), p. 179.

14 Baron and Epstein (1997), p. 168.

15 Baron and Epstein (1997); Starski (2018).

16 Baron and Epstein (1997), p. 149, see also p. 151.
} 
by the argument that, if economic coercion does not constitute force, neither should a cyberattack on the New York Stock Exchange. ${ }^{17}$ But to view the same piece as a narrative about what the law is or should be raises a different set of questions. Rather than asking which interpretation is the most convincing, we might want to know who is doing the storytelling and in what way; who are the main characters in the narrative and how they are portrayed.

Specifically, in this article I want to consider these stories about cyberattacks and international law as plot-driven: the writer of the piece sets out to solve the legal problem of cyber operations and, as readers, '[w]e want to know the story'-we want to know 'how it ends'. ${ }^{18}$ I will elaborate on the notion of 'plot' below, but for now it suffices to point out what it does analytically: it puts the writer in the spotlight as she 'temporally unfolds' the text to the reader. ${ }^{19}$ 'Plot' is that which exposes the presence of the writer in the text as well as that which is aimed at making the reader continue reading. ${ }^{20}$ Yet when we read an individual article or book chapter we are hardly aware of the writer, guiding us through the text. ${ }^{21}$ The writer hardly seems to figure ${ }^{22}$ in what we absorb when we read. But 'texts do not [...] write themselves', and the same goes for law and legal scholarship. ${ }^{23}$ Thus, my aim in thinking about these articles on cyberattacks and international law in this way is to show where and how in these academic texts the writer attempts to model the reading experience. A different way of phrasing this is that the words chosen by a writer impact what we think the law is in a particular field, yet, 'as a reader, you hardly notice that you're not free when you're reading a text'. ${ }^{24}$ So my aim here is to show where those restrictions on our reading experience-the boundaries of what is and is

\footnotetext{
17 For a discussion see, for example, Gervais (2012), pp. 550-551; Lin (2010), p. 74; Barkham (2001).

18 Porter Abbott (2007), p. 40. For other analyses of legal scholarship and/or law as plot-driven, see Paskey (2014); Starski (2018), pp. 11-12; West (1985). The choice of the noun 'writer' rather than 'author' in this piece is deliberate in order to avoid confusion with debates on authorship in literary theory. Although this article may, at various points, call those debates to mind, I omit any mention of them here. The scope of the article does not allow me to do them justice: it allows for one argument only, which is the textual, 'tangible' presence of the writer.

19 On 'temporal unfolding', see Brooks (1992), p. xii; see also Brooks (2006), p. 16. Brooks understands plot as 'so basic to our experience of reading [...] that criticism has often passed it over in silence' (Brooks (1992), p. xi; see also p. 14). See also Sect. 3, below. In using feminine pronouns I follow Laura Henderson in Henderson (2018), p. 12, fn. 1.

20 Brooks (1992), p. xiii. On the presence/absence of the writer, see Baron and Epstein (1997), p. 151; Brooks (1992), p. 86; on the reader, see Brooks (1992), p. 14.

21 Bentley refers to plot as 'result[ing] from the intervention of the artist's brain'. See Bentley (1965), p. 15.

22 Wetlaufer (1990), p. 1568, fn. 60.

23 Woodmansee and Jaszi (1994), p. 1. With regard to 'narratives of progress' in international law Thomas Skouteris writes that they 'do not "speak themselves": their plot is not objectively true. Instead, their plot is constructed by the author, based on concrete (epistemic, ideological, other) choices and is manifested through a vocabulary - a set of assumptions, images, metaphors, and other discursive structures'. Skouteris (2008), p. 1.

24 'Als lezer heb je maar amper door dat je niet vrij bent in het lezen van de tekst'. My own translation from Brillenburg Wurth and Rigney (2006), p. 210. Similarly, Stephen Paskey writes how 'the author must $[\ldots]$ choose the words by which' she tells the story. Paskey (2014), p. 80.
} 
not law-are imposed by the writer. ${ }^{25}$ In short, I want to show that these are people writing law, and they can be made visible in their own texts.

The article is structured as follows. In Sect. 2 I will situate this piece in relation to literary theory and law and literature scholarship specifically, elaborating on different notions of the concept of 'narrative' and what it does for the study of law. ${ }^{26}$ In Sect. 3 I move on to explain, with reference to the work of Peter Brooks, ${ }^{27}$ my understanding of 'plot' as a specific element of narrative. To explain what I mean when I claim that 'plot' exposes the presence of the writer in the text, I also discuss the example of metatext in scholarship. Metatext roughly means 'text about text ${ }^{\text {'28; }}$ phrases such as 'in section $2 \mathrm{I}$ will situate this piece...' By these means writers explicitly 'manifest' ${ }^{29}$ themselves in the text, and a discussion of metatext will therefore hopefully help in explaining what I mean by plot as similar-though perhaps less obvious ${ }^{30}$ - proof of the writer's presence. ${ }^{31}$ Section 4 concludes the article.

A note on my choice of subject as well as my method is in order. As is apparent from this introduction, in this piece I use the debate on cyberattacks and international law to illustrate how plot and metatext signal the presence of the writer in the text. The reason for singling out this debate is precisely because legal scholars have played such a prominent part in it: for years, states have kept quiet on how they think international law applies to cyberattacks. This means that the space afforded to legal scholars to come up with their own solutions is much bigger than if there had been a plethora of state practice. ${ }^{32}$ It is therefore an interesting debate for numerous reasons, one of which is that international legal scholars are so visible as the ones coming up with international law as we know it. ${ }^{33}$

Finally, a note on method. Previously, the 'interdisciplinary [...] analysis of narratives, ${ }^{34}$ —narratology — was concerned with the common elements of narratives. ${ }^{35}$ This approach entails a search for stories' 'underlying structures', a 'model' that would apply to the way narratives proceed 'across time and cultures'. ${ }^{36}$ However, in this article I follow (to a degree ${ }^{37}$ ) Peter Brooks' approach to plot, which deals with how plot 'drive[s] the text forward', 'with how narratives work on us, as

\footnotetext{
25 See also Brooks (2006), p. 10; Baron and Epstein (1997), p. 151.

26 This question is more elaborately and functionally dealt with by both Baron and Epstein (1997) and Starski (2018).

27 Specifically Brooks (1992).

28 See also Hyland (2004), p. 109.

29 Hyland (2004), p. 109, who refers to the 'manifestation of the author' in the text. See also Sect. 3.

30 Baron and Epstein (1997), p. 151.

31 Writing about metadiscourse in academic writing Ken Hyland uses the exact same phrase. See Hyland (2002), p. 355.

32 Ziolkowski (2012), p. 297; Schmitt (2013), p. 5; see also Boer (2017), para. 2.2.

33 I explore this debate in greater depth in Boer (2017).

34 Brillenburg Wurth and Rigney (2006), p. 425, my translation.

35 Brillenburg Wurth and Rigney (2006), p. 174.

36 Brillenburg Wurth and Rigney (2006), pp. 174, 175, my translation.

37 Brooks moves on to explain how he applies a Freudian perspective on plot, which I do not follow here.
} 
readers' ${ }^{38}$ This means that in this article I focus on what the plot of an individual piece of scholarly writing does for the overall legal argument: how the steps a scholar takes in her legal reasoning 'drive the argument forward' toward a seemingly inevitable ending. ${ }^{39}$ Importantly, this 'work' done on the reader by means of plot and metadiscourse is work done by the writer on an imagined reader-imagined by the writer. ${ }^{40}$ Writing about metadiscourse Geoff Thompson states how it is aimed at the 'reader-in-the-text', or 'the reader as enacted by the writer'. ${ }^{41}$ My analysis therefore aims to uncover how the writer presumes her reader will 'respond', as 'evidence[d] from the text'. ${ }^{42}$ What this means is that I am concerned with the textual, 'tangible' presence of the writer in her text.

\section{On Stories and Narratives: A Brief Introduction}

As the Cambridge Companion to Narrative states, '[i]n informal usage, narrative is a synonym for story'. ${ }^{43}$ Normal language use does not differentiate between the two, and in the introduction to this article 'narrative' and 'story' were similarly used interchangeably. However, in literary theory a distinction is made between 'story' and 'narrative' - and the same distinction will be maintained in the remainder of this text. ${ }^{44}$ The basic idea is that 'a story is separate from its rendering'. ${ }^{45}$ What this means is that a narrative can be organized in different ways, all the while referring to the same order of events (the story). Simply put, 'something' is being told in a particular way: the 'something' here being the story; its rendering the narrative. ${ }^{46}$ More comprehensively defined, a narrative,

\footnotetext{
38 Brooks (1992), pp. xiv, xiii. For this change of focus in narratology at large, see Brillenburg Wurth and Rigney (2006), pp. 174-175.

39 Wetlaufer (1990), p. 1571.

40 Thompson (2001), p. 60.

41 Thompson (2001), p. 60.

42 Thompson (2001), p. 60.

43 Herman (2007), p. 279 (emphasis omitted).

44 For a problematization of this definition of narrative, see Ryan (2007).

45 Porter Abbott (2007), p. 40. He points out that this goes back to the distinction made by Russian Formalists between fabula and sjuzhet (p. 41; see also Brooks (1992), pp. 12-13). Porter Abbott explains that the origins of the distinction lie in the Saussurian distinction between signifier and signified. He also states, however, that the idea that a story might be narrated in different ways ultimately raises the question of 'how [...] we know it is the same story when we see it again?' In Saussurian terms, how do we know different signifiers refer to the same signified thing? See Porter Abbott (2007), p. 41. Note that Brooks nonetheless argues in favour of upholding the distinction, as story and narrative represent "two modes of order' (p. 13). For more, see Brooks (1992), p. 13; Brooks (2006), pp. 23-24.

46 The way I phrase narrative here comes close to the definition of narration, or ' $[\mathrm{t}] \mathrm{he}$ process by which a narrative is conveyed' and this includes, for example, the medium and personal pronouns used; see Herman (2007), p. 279.
} 
is a representation of (i) a structured time-course of particularized events that

(ii) introduces conflict [...] into a storyworld [...] conveying (iii) what it's like to live through that disruption. ${ }^{47}$

In other words, narrative is about the conscious effort on the part of the writer to construct a particular reality by 'structuring events', 'introducing a problem' and conveying 'what it's like' to experience that problem. Although there are multiple definitions of narrative around, the difference between story and narrative as such is informative in that it highlights that what we call narrative is a very specific representation of a story: 'the chronological sequence of situations and events' ${ }^{48}$ may be told in many different ways.

Legal scholars have, for some time now, paid attention to the way legal stories are told. ' $[\mathrm{L}] \mathrm{aw}$ is awash in storytelling', ${ }^{50}$ Anthony Amsterdam and Jerome Bruner state, and the most obvious example might be the stories told in a courtroom:

Clients tell stories to lawyers [...] As clients and lawyers talk, the client's story gets recast into plights and prospects, plots and pilgrimages into possible worlds [...] If circumstances warrant, the lawyers retell their clients' stories in the form of pleas and arguments [...] Next, judges and jurors retell the stories to themselves or to each other in the form of instructions, deliberations, a verdict, a set of findings, or an opinion. And then it is the turn of journalists, commentators, and critics. This endless telling and retelling, casting and recasting is essential to the conduct of the law. ${ }^{51}$

Narratives, Amsterdam and Bruner claim, are crucial to our understanding of 'what happened' 52 in a particular case, and the easiest way to grasp why they matter is by focusing on their rhetoric. Marianne Constable points out that there is a difference between saying 'the man dropped the package' versus 'the package was dropped by the man' for our understanding of exactly the same situation. ${ }^{53}$ Constable explains how the first phrase - the man dropped the package-places responsibility for dropping the package squarely with 'the man', simply by virtue of its grammar. The man is the acting subject in this phrase, she states; he is the one dropping the package. Conversely, 'the package was dropped by the man' is far less direct: written in the passive voice 'the man' moves into the background and instead, something

\footnotetext{
47 Herman (2007), pp. 279-280.

48 Herman (2007), p. 281; see also Brooks (1992), p. 13. See also Starski (2018), p. 9 and Baron and Epstein (1997), pp. 144-145, on the difficulty - also within literary theory-of defining these terms.

49 Peter Brooks situates the start of this scholarship with Robert Cover's Nomos and Narrative (Cover (1983)), and subsequently with a special issue of the Michigan Law Review on 'Law and Literature' in 1989 (volume 87). See Brooks (2006), p. 1. For the identification of a different beginning, see Rideout (2008), pp. 53-54.

50 Amsterdam and Bruner (2000), p. 110; see also Baron and Epstein (1997), p. 141.

51 Amsterdam and Bruner (2000), p. 110. See also James Boyd White, Heracles Bow, cited in Rideout (2008), p. 53.

52 Brooks (2006), p. 25; Brooks and Gewirtz (1996), pp. 7-12.

53 Constable (2014), chapter 2, specifically pp. 50-57; Baron and Epstein (1997), pp. 142, 147; on rhetoric, pp. 146-147.
} 
happens to 'the package'. ${ }^{54}$ This shows, at a micro-level, why narrative matters: these are all different accounts (narratives) of the same event (or story) and the account we adhere to determines what we think happened-and thus matters to legal outcomes. ${ }^{55}$ In the words of Peter Brooks, 'our tellings reorganize events' ${ }^{56}$ and it is not for nothing, he adds, that US Supreme Court opinions end with the phrase, '[i]t is so ordered' 57 This is not just a Court making a final decision as to how the law applies in a particular case: the decision itself is a choice to 'order' ${ }^{58}$ a story in a particular way.

Stephen Paskey takes this notion of narrative and law even one step further and argues that all law is narrative. Narrative emerges not just in the statement of a rule and its application to a concrete case: he claims that 'the elements of [a] rule correspond to the elements of a story and have a logical relationship that qualifies as a "plot". 59 '[E]very governing rule demands a story', he writes: the set-up of every rule is, in itself, a story, and therefore demands that its application proceeds according to a specific narrative ('stock stories', in his words). ${ }^{60}$

Law and literature scholars ${ }^{61}$ thus mainly focus on court cases and legal briefs, but the focus of this article lies specifically on legal scholarship as narrative. Paulina Starski points out that '[w]ithin academic contributions, sequences of events, climaxes, imageries, personas, myths, scenarios [...] and "narrative closures" can be identified'. ${ }^{62}$ Legal scholarship, as much as judges' rulings and lawyers' defence of their clients, 'can also be seen to tell stories about what the law is or could be'. ${ }^{63}$ Viewed as such, plot has a particular explanatory function when looking at legal scholarship: it is that which moves the narrative forward. ${ }^{64}$ As stated in the introduction, in this article the notion of 'plot' serves the purpose of exposing the presence of the writer in the text; someone who exercises control over the 'order' in which we

\footnotetext{
${ }^{54}$ Constable delves into the Palsgraf judgment at the US Supreme Court, see Constable (2014), chapter 2. On this case and its narratives, see also Brooks (2006), pp. 13-17.

${ }^{55}$ Constable (2014), chapter 2; Brooks (2006), p. 3.

${ }^{56}$ Brooks (2006), p. 24.

57 Brooks (2006), p. 26.

${ }^{58}$ Infra n. 73. More elaborately, Sect. 3.

${ }^{59}$ Paskey (2014), pp. 52, 71.

${ }^{60}$ Paskey (2014), pp. 52, 75.

${ }^{61}$ Or, to follow Brooks and Gewirtz, law as literature. They point out that the 'law and literature' stream also has a branch focusing on law in literature. The first, however, is where this research is embedded. See Brooks and Gewirtz (1996), pp. 3-4. Law and literature scholarship also focuses on how dominant narrative modes might exclude other kinds of storytelling. Law is narrated by means of a particular 'form, structure, and rhetoric' (Brooks and Gewirtz (1996), p. 4) and this is not necessarily, as some scholars claim, to the benefit of the narratives told by women or minority groups (Delgado (1989), specifically pp. 2412-2413; Cook (1994) and Brooks and Gewirtz (1996), pp. 5-6; Baron and Epstein (1997), pp. 176 et seq.). This turns the 'law and literature' move on its head, as it involves a call for different kinds of legal writing, including literature as law or legal writing (Cook (1994); Baron and Epstein (1997), pp. 178-179). See also Starski (2018), p. 1.

${ }^{62}$ Starski (2018), p. 11, in-text reference omitted.

${ }^{63}$ Baron and Epstein (1997), p. 149; Brooks and Gewirtz (1996), p. 5; Paskey (2014), p. 77; Bandes (1996), p. 385 cited in Baron and Epstein (1997), p. 149, fn. 30; for a discussion of and a response to critiques on this approach, see Baron (1994).

${ }^{64}$ Paskey similarly refers to plot as 'a sequence of events with some sense of movement'. Paskey (2014), p. 65.
} 
as readers receive the information about the law that is applied. The outcome of the law-application in question may be told right away or not revealed until the very end of the piece-but in both instances plot decisions are being made by the writer. ${ }^{65}$ Therefore, in the next section I will draw on the notion of plot to show where the writer takes control of the way in which we are familiarized with the outcome of 'legal problem-solution'. ${ }^{6}$

\section{Plot and the Presence of the Writer}

Plot, in literary theory, is 'an even slipperier term than narrative'; 'polyvalent' and 'vague in ordinary usage'. ${ }^{67}$ When literary theorists discuss what plot 'does' for a narrative they use phrases such as 'the itch to find out', 'narrative with something "done to it", or the 'temporal unfolding' of the narrative. ${ }^{68}$ But however vague it may be and however much it may lack a uniform definition, the notion of plot seems to point in the direction of that which moves the story along: '[w]e want to know the story'. ${ }^{69}$ What literary theorists refer to when writing about 'plot' is the idea of the 'management of suspense' and the expectations the reader has about where the narrative is going next. ${ }^{70}$ This also highlights the crucial role played by the reader in the experience of plot. ${ }^{71}$ There is no plot without a reader there to absorb it: 'the reading of plot [is] a form of desire that carries us forward, onward, through the text'. ${ }^{72}$ As an example, consider how this article starts anecdotally with a reference to the book by Thomas Wingfield. This is a conscious effort on my part to (hopefully) draw in the reader, urging her along. So 'plot' has a lot to do with the way a narrative is structured. Legal scholarship, as does fiction, presents a certain kind of 'ordering', ${ }^{3}$ a decision made by a writer to present events-legal interpretation-in one way rather than another. This choice about order subsequently impacts the 'experience of reading': plot is 'goal-oriented and forward-moving'. ${ }^{74}$ If, then, plot is equated with leaving the reader in suspense, textual ordering as a very "careful decision' ${ }^{75}$ by the writer turns into a structuring device.

As a starting point, and to show what I mean by plot as a structuring device, I turn to a concrete example of legal scholarly writing. The example I use here is a

\footnotetext{
65 Brillenburg Wurth and Rigney (2006), pp. 181-182.

66 Koskenniemi (2005), p. 60.

67 Porter Abbott (2007), p. 43; 'vague in ordinary usage' is a quote Porter Abbott uses from RimmonKenan (1983), p. 135.

68 Bentley (1965), p. 31; Bentley (1965), pp. 14, 15; Brooks (1992), p. xii.

69 Porter Abbott (2007), p. 40, emphasis added; Forster (1990 [1927]), p. 87; Brooks (1992), p. xiii.

70 Porter Abbott (2007), p. 40; Bentley (1965), pp. 29-30; Brillenburg Wurth and Rigney (2006), pp. 216-217.

71 Brooks (1992), p. 14.

72 Brooks (1992), p. 37.

73 Brooks (1992), p. 13; Porter Abbott (2007), p. 40; Brillenburg Wurth and Rigney (2006), p. 173.

74 Brooks (1992), pp. xi, 12.

75 Hyland (2004), p. 116; see also Baron and Epstein (1997), p. 168.
} 
book chapter written about the application of the jus ad bellum to attacks perpetrated by states in cyberspace. The debate the writer refers to is that on the meaning of the prohibition on the use of force, found in both customary law as well as Article 2(4) of the Charter of the United Nations. Most scholars claim that the meaning of the word 'force' - at least in the context of international law-is restricted to the use of military or armed force, and that it takes some interpretive effort to include cyberattacks. ${ }^{76}$ The question that is central to their writing is whether the prohibition on the use of force allows for extension towards cyberattacks and, if so, how. However, my concern here is not with the substance of these claims: rather, I wish to point out the way in which they are presented.

The chapter in question is taken from James Green's Cyber Warfare: A Multidisciplinary Analysis: an edited volume containing a variety of contributions on the issue of cyber warfare from a wide range of writers. ${ }^{77}$ The topics they address include the jus in bello as it applies to cyberattacks, the just war tradition and the problem of attribution in cyberspace. Green himself wrote the chapter on the applicability of the jus ad bellum. Two pages into his chapter it is already clear what he will argue: that the debate on Article 2(4) and cyberattacks glosses over the fact that the application of these rules will be obstructed by the (legal and technical) difficulty of attributing cyberattacks. ${ }^{78}$ Those first couple of pages serve as a summary of the chapter as a whole: Green starts with the problem statement that 'at present, there are no specific rules of international law governing the interstate use of cyber force'. He then moves on to list several scholarly efforts to nonetheless give concrete meaning to existing law, concluding that the 'majority view [...] is that the existing rules of international law are applicable [...] to cyber warfare'. Added to this then is his own view: '[t]he first part of this chapter', he writes, 'sets out [the] debate as to the correct interpretation of Article 2(4)', but will conclude-we are told-that it is 'extremely difficult to determine whether Article 2(4)' 'works' in cyberspace. Subsequently, '[the] chapter goes on to argue' that whatever the correct interpretation of Article 2(4), the lower threshold of the non-intervention principle means that 'resort to cyber warfare will in most cases be unlawful'. However, both the prohibition on the use of force as well as the non-intervention principle suffer from the problem of attribution: it is often unknown who the attacker is, and scholarly proposals to come up with a treaty to regulate cyberwar specifically suffer from the same fate. Therefore, Green announces he will conclude the chapter by proposing a focus on the due diligence principle.

The decision made by Green to inform his readers from the outset what 'the chapter' will argue immediately clarifies how we are to read the remainder of his chapter and what its overall claim is. These choices made by a writer-whether to

\footnotetext{
76 On this debate see, for example, Schmitt (1999), Barkham (2001), Silver (2002), Harrison Dinniss (2014) and Boer (2015). On the claim that 'most scholars agree', see Boer (2016).

77 Green (2015).

78 All quotes in this paragraph are from Green (2015), pp. 96-98. For 'Problem-Solution' as a 'text pattern', see Thompson (2001), p. 59.
} 
summarize the whole piece in the introduction or not ${ }^{79}$ - are choices about order: they aim to structure the 'experience of reading'. James Green's introduction is a push in a very distinct direction; a push toward a reading experience different from a chapter introduction that claims to present an overview of existing law. Green's is a normative claim about, to put it bluntly, what is wrong with the law and how it can be fixed. As an alternative, consider the introduction of Marco Roscini's chapter on the same topic: the application of the jus ad bellum to cyberattacks. ${ }^{80}$ As does James Green, in his introduction Marco Roscini presents an overview of his chapter. However, there is no sense here of a main claim or of a very strong argument as to whether or not cyberattacks allow for regulation under existing laws of war. Instead, he writes how the overall aim of the chapter is to 'discuss how the Charter's provisions on the use of force apply to cyber operations'. In order to do so, '[i]t will first explore if and when a cyber operation amounts to a use of force', followed by a 'discuss[ion] whether the state victim of a cyber operation can invoke the right of self-defence by cyber or kinetic means against it'. The chapter then 'analyse[s]' '[r]emedies against cyber operations below the level of armed attack [...] before turning to the role that the UN Security Council can play in relation to cyber operations'.

This is where his introduction stops. At this point in the text we have no idea what Marco Roscini will eventually conclude with regard to the legal issues he raises; we are merely presented with an overview of what he will discuss. Interestingly, this sense of 'merely' presenting an overview, the much less explicit tone adopted by Roscini in his introduction, is mirrored in his conclusion. He summarizes his 'findings' in six, numbered points, followed by two tables presenting a '[q]ualification' of cyberattacks as well as possible remedies. ${ }^{81}$

Considering how plot is the 'temporal unfolding' of the narrative, 'carrying us forward, onward, through the text' the effects achieved by these two introductions are very different. James Green's introduction pushes us toward a very explicit conclusion about how the law works in this field and what is wrong with it. By contrast, the experience of reading Roscini's introduction is the exact opposite: there is a calmness to it and an almost reassuring sense that, at the end of this chapter, we will have been informed 'what the law is'.

This writing towards a certain conclusion does not just happen, obviously, by means of an introduction: it happens throughout a text by means of 'subplots', if you like-twists and turns in a text that direct the narrative towards its ultimate conclusion about what we are told by the writer is or should be law. ${ }^{82}$ In order to better explain what I mean when I claim that this exposes the presence of the writer, the next section takes a closer look at some legal texts. I start by looking at their metadiscourse: the words by means of which these writers explicitly organize their texts, either by structuring it or by adopting a specific position. ${ }^{83}$ This then serves to

\footnotetext{
79 On the order of narratives, see Brillenburg Wurth and Rigney (2006), pp. 181-182.

80 Roscini (2014), chapter 2. All quotes in this section are taken from pp. 43-44 of his book.

81 Roscini (2014), pp. 115-116.

82 On the interpretive turns taken in these pieces, see Boer (2017), chapter 3.

83 Hyland (2004), p. 111.
} 
revisit the plot of their work and to ask again how we are directed towards a conclusion about the meaning of law.

\subsection{Taking a Closer Look}

As a start, let's return to James Green's chapter on the jus ad bellum and cyberspace. A few pages in Green elaborates on the meaning of the word 'force' in Article 2(4). After first positing that the prohibition on the use of force is not limited to attacks against the 'territorial integrity or political independence' of the state, but covers all uses of force, Green states the following:

While it can be said that all 'uses of force' are covered by Article 2(4)'s prohibition, this begs a much more problematic question for the regulation of cyber warfare under the jus ad bellum: do interstate cyber-attacks qualify as 'uses of force' in the first place? The primary debate in the international law literature, which has raged since the late 1990s, is whether a cyber-attack equates to 'force' as per Article 2(4). If so, then such action is prohibited by that article; if not, rather obviously, it falls outside of its reach. Unfortunately, Article 2(4) itself does not define what it means by 'force'. Long before the advent of cyberspace, states and scholars therefore debated what was included in the term and what was not. In particular, the question was whether actions such as economic and political coercion should be considered 'force' for the purposes of Article 2(4), or whether the provision is restricted to what might be termed 'armed force' (i.e. troop movements, gunfire, explosives and so on) [...] The starting point for interpreting the meaning of provisions of a treaty is to consider [their] ordinary meaning $[\ldots]^{84}$

Printed in bold in the quote above are the metadiscursive elements in Green's text. Metadiscourse refers to 'those aspects of the text which explicitly refer to the organisation of the discourse or the writer's stance towards either its content or the reader'. ${ }^{85}$ As an example from my own text: at the end of the previous section I announced what I would discuss in this one. This is 'textual metadiscourse', to be more precise, an 'endophoric marker' which ' $[\mathrm{r}] \mathrm{efer}[\mathrm{s}]$ to information in other parts of the text'. ${ }^{86}$ We also find these 'endophoric markers' in the introduction of Green's chapter: he writes that '[t]he first part of this chapter sets out...'; it then 'goes on to argue' and '[n]ext [...] considers' ${ }^{87}$ Writing about metadiscourse, Thompson refers to these words as 'involv[ing] the management of the flow of information and thus serv[ing] to guide readers through the content of the text' ${ }^{88}$ This is not the only

\footnotetext{
${ }^{84}$ Green (2015), p. 100; in-text quotation mark omitted.

85 Hyland (2004), p. 109.

86 Hyland (2004), p. 111. Note other classifications are possible; see Thompson (2001), and for further references Hyland (2004), p. 111.

87 Green (2015), p. 97.

88 Thompson (2001), p. 59. Note that Thompson does not use the word 'metadiscourse'; instead he refers to 'interaction'. This he then divides into 'interactive' and 'interactional' elements, which cor-
} 
way the writer directs our thoughts, however: Hyland refers to the second category of metadiscourse as 'interpersonal'. ${ }^{89}$ By means of these words the writer communicates how she 'feels' about the claims she puts forward. ${ }^{90}$ For example, James Green writes how 'unfortunately, Article 2(4) itself does not define what it means by "force"". This is an example of an 'attitude marker" 91 by means of which we come to know how James Green 'feels' about Article 2(4) itself not defining what it means by force. It paves the way for what we read in the next sentence: that 'states and scholars therefore debated what was included in the term and what was not'.

Words such as 'whether', 'if so' followed by 'if not', 'therefore', 'in particular', and 'the starting point' all structure the text and are all 'strateg[ies] for guiding the reading process'. ${ }^{92} \mathrm{We}$ are told how a phrase relates to the one preceding it, and there are numerous qualifications James Green gives in relation to the debate his piece deals with. Similarly, the four paragraphs following the one quoted above all start with phrases that may be read sequentially: '[t]he starting point for interpreting [...] a treaty', '[e]lsewhere in the UN Charter', '[o]ther scholars, however, have...', and '[a]lso potentially supporting a more restrictive reading...' They furthermore contain words such as 'might well suggest', 'certainly arguable', 'entirely contradictory', 'strongly indicates' and 'perhaps should'. ${ }^{93}$ This is the text being 'unfolded' by the writer, and the way it unfolds is through 'various kinds of textual clues that writers give to readers'. ${ }^{94}$ In this way we are told a particular narrative about the meaning of force, and at the end of it James Green tells his reader that these "interpretive gymnastics" ${ }^{95}$ really have not got us anywhere.

Ken Hyland, whose model of metadiscourse is used in this section, describes metadiscourse as the way in which 'writers project themselves into their work' 96 Something 'might well suggest'; alternatively, it may 'strongly indicate'; something is 'certainly arguable' or 'perhaps should' be read differently. ${ }^{97}$ By means of these phrases the writer constantly makes an appearance in the text, qualifying terms and directing our focus. This is one of the ways in which 'authorial control' 98 may be exercised by the writer, and it aims to affect how we perceive certain claims. For example, rather than claim that it is 'unfortunate' that Article 2(4) 'does not define what it means by "force", Green could also have considered it fortunate that it does

\footnotetext{
Footnote 88 (continued)

respond with Hyland's 'textual' and 'interpersonal' categories of metadiscourse. See Hyland and Tse (2004), p. 168.

${ }^{89}$ Hyland (2004), p. 111.

90 Hyland (2004), p. 112.

91 Hyland (2004), p. 113.

92 Hyland (2004), p. 114.

93 Green (2015), pp. 100-101.

94 Thompson (2001), p. 58. Hyland and Tse refer to metadiscourse as 'the writer's awareness of the unfolding text as discourse: how writers situate their language use to include a text, a writer, and a reader'. See Hyland and Tse (2004), p. 167, emphasis in the original.

95 Green (2015), p. 101.

96 Hyland (2004), p. 109.

97 See also Brillenburg Wurth and Rigney (2006), p. 175.

98 Porter Abbott (2007), p. 47.
} 
not do so. After all, arguably this openness allows for the inclusion of new ways of waging war-such as cyberattacks. So to point out how 'authorial control' is exercised is really no different than saying that this narrative could have been told differently, but that it wasn't. ${ }^{99}$

The same holds true for an article's or a book chapter's narrative at large. Zooming out from the metadiscursive level to the plot twists in Green's text, we see the way in which the writer orders what he 'knows' about the law. ${ }^{100}$ Basically, the paragraphs referred to above constitute a narrative about the boundaries of Article 2(4). ${ }^{101}$ It starts with a very specific way of talking about the history of the prohibition on the use of force: a "method of "historization", Paulina Starski names it, in which legal scholars 'display how specific norms have evolved, in which historical setting they were enacted and how they used to be interpreted by jurisprudence'. ${ }^{102}$ In the narrative that Green presents, this little bit of history provides a jumpingoff point for a discussion of the 'secondary method of treaty interpretation': the travaux of the UN Charter. ${ }^{103}$ Concluding that these reveal that force should be read as armed force, Green discusses several attempts by scholars to see whether cyberattacks could be considered as such-as armed force. Not surprisingly given what he announced in the introduction of his chapter, none of these suffices: a couple of pages further on we are told that the debate on Article 2(4) is both 'exhaustive and exhausting'. ${ }^{104}$ This, again, is a sub-plot: it opens up space for a move towards a discussion of the non-intervention principle.

The point of these sub-plots in the text is precisely to induce a sense of inevitability to our 'findings' and the conclusions we 'draw' ${ }^{105}$ The narrative James Green presents about the meaning of law is ordered in a very specific way, telling a very specific story about what the law is and why this debate has developed the way it has-and what would be the more obvious legal solution for the problem of cyberattacks. Scholars' inconclusive 'interpretive gymnastics' might ultimately point in the direction of the due diligence principle; but alternatively, the uncertainty surrounding the application of Article 2(4) leads them to construct a tool that should help state legal advisors evaluate cyberattacks as close as possible to the UN Charter framework. ${ }^{106}$

This emphasis on the order in which a narrative is told, and what that order 'does' for our overall experience of the strength of the argument, is precisely what happens when we consider legal scholarship as driven by a particular plot. In the Preface to Reading for the Plot Peter Brooks states that

\footnotetext{
99 Toolan (2007), p. 231; Wetlaufer (1990), p. 1571. See also the discussion of Mansfield Park, below.

100 For linguistic analyses of narratives see Toolan (2007) (of fiction) and Amsterdam and Bruner (2000) (of law).

101 See also the discussion of and references to Paulina Starski's work elsewhere in this piece.

102 Starski (2018), p. 12.

103 Green (2015), p. 101.

104 Green (2015), p. 107.

105 On 'finding' the law in its sources, see Koskenniemi (2000), p. xvi; Schlag (1991), p. 1645; on the apparent inevitability of legal conclusions, see Wetlaufer (1990), p. 1571.

106 As done by Schmitt (1999).
} 
[e]ven more than with plot [...] I shall be concerned with plotting: with the activity of shaping, with the dynamic aspect of narrative- that which makes a plot 'move forward,' and makes us read forward, seeking in the unfolding of the narrative a line of intention and a portent of design that hold the promise of progress toward meaning. ${ }^{107}$

Brooks talks here of 'the activity of shaping', 'a line of intention' and the 'portent of design'. If we apply this notion of 'plotting' to legal scholarship, one way of understanding Brooks' point is that the way in which our research proceeds is not the same as the way we eventually write down our findings. ${ }^{108}$ We can even attempt to visualize how this happens: as writers, we sit behind our desks trying to come up with the phrases and formulations that will work best to convey our points. There is a difference between our 'research acts' and our 'writing acts' ${ }^{109}$ between the order in which we consult our books and journal articles and the way in which we eventually write down what we found there. To explain what I mean, consider an example from a chapter written by Nicholas Tsagourias about 'the legal status of cyberspace'. ${ }^{110}$ The chapter deals, inter alia, with questions of jurisdiction and sovereignty in cyberspace, and includes a discussion on whether cyberspace may be seen as a global commons. Concluding his chapter Tsagourias writes the following:

It is apparent from the preceding discussion that cyberspace has not acquired any special legal status in international law but instead existing legal categories and principles have been applied to cyberspace. By doing so, a non liquet has been avoided; a finding that is of a substantive or interpretative gap in international law. ${ }^{111}$

This paragraph is clearly aimed at flagging a conclusion for the reader: if I have read the chapter in its entirety and followed Tsagourias' arguments this far, I can also see how he comes to claim that 'a non liquet has been avoided' (though, of course, I may still substantively disagree). The application of law is presented here as steadily advancing towards a certain inevitable outcome. '[O]ur arguments aspire to the linearity of a geometric proof', Gerald Wetlaufer writes: if X, then Y must follow logically. ${ }^{112}$ Yet the fact that they were written down in order to be experienced as such by the reader-Brooks' 'activity of shaping' — should be enough to make us wonder about the writer. Legal doctrinal scholarship presents a narrative which 'temporally unfolds' towards a certain outcome - the plot ${ }^{113}$ of a legal argumentbut the writer already knows how it ends. Viewed like this, the 'finding' that 'a non

\footnotetext{
107 Brooks (1992), p. xiii.

108 Infra n. 109.

109 Bunton (1999), p. 47 cited in Hyland and Tse (2004), p. 166. Note that there seems to be a slight difference between the way Hyland and Tse interpret Bunton's distinction, and the way he himself explains it. I am adopting the distinction as made by Hyland and Tse here.

110 Tsagourias (2015).

111 Tsagourias (2015), p. 28.

112 Wetlaufer (1990), pp. 1571, 1572.

113 Brooks (1992), p. xiii.
} 
liquet has been avoided' gains a different flavour. ${ }^{114}$ Brooks writes that 'prior events, causes, are so only retrospectively, in a reading back from the end'. He adds how we may compare the application of law in an individual article or book chapter with a

detective story [...] using the plot of the inquest to find, or construct, a story of the crime which will offer just those features necessary to the thematic coherence we call a solution, while claiming, of course, that the solution has been made necessary by the crime. ${ }^{115}$

This reveals the juxtaposition of the reader's experience of the 'temporal unfolding' of the answer to a legal problem, versus the writer's 'intervention' ${ }^{\text {, }}{ }^{16}$ in portraying this 'legal problem-solution' as a linear process. Those who narrate have the benefit of hindsight: '[n]arrative [...] is retrospective', ${ }^{117}$ yet experienced in the completely opposite direction by the reader. ${ }^{118}$

\section{In Conclusion: The Present Writer}

When it first came out in 1999, many reviewers of the film Mansfield Park noted the extent to which its storyline deviated from the original novel. ${ }^{119}$ The film merges the novel's main character, Fanny Price, with the life of the novel's writer, Jane Austen, and according to some critics this meant the film was taking too many liberties with the original story. ${ }^{120}$ The blend between the 'life' of Fanny Price and that of Jane Austen also emerges at the end of the film, when Fanny Price addresses the audience by means of a voice-over. While pondering the different ways the characters end up in the narrative and how their lives could have ended up differently, she says, 'it could have all turned out differently I suppose. But it didn't'. ${ }^{121}$ We may add, 'and it wouldn't'. ${ }^{122}$ Considering that this may be also the writer of the novel speaking ${ }^{123}$ the

\footnotetext{
114 The word 'artificial' is used by several writers in this context: see, for example, Herman (2007), p. 277; Bentley (1965), p. 15; Baron and Epstein (1997), p. 169.

115 Brooks (1992), p. 29; Brooks (2006), p. 16. Similarly, White (1987), p. 21, cited in Skouteris (2008), p. 18.

116 On the 'artist's intervention', see Bentley (1965), p. 15.

117 Brooks (2006), p. 16.

118 Brooks (1992), p. xi; see also p. 14.

119 E.g. https://www.nytimes.com/1999/10/31/movies/film-making-an-austen-heroine-more-like-auste n.html; https://www.rogerebert.com/reviews/mansfield-park-1999 (accessed 1 March 2019).

120 E.g. http://www.filmvault.com/filmvault/austin/m/mansfieldpark1.html (accessed 1 March 2019); for a discussion see Aragay (2003); see also Moussa (2004). Interestingly, the film critic Roger Ebert countered these critiques by saying that 'anyone who thinks [the film] is not faithful to Austen doesn't know the author but only her plots'. See https://www.rogerebert.com/reviews/mansfield-park-1999 (accessed 1 March 2019).

121 Mansfield Park (1999), Miramax Films, BBC Films and Intermedia Films in association with The Arts Council of England, written and directed by Patricia Rozema, at 1:42:42.

122 A similar observation is made by Monaghan (2007), p. 99, but in reference to Fanny Price herself as a writer-and by extension, to Patricia Rozema as the writer of the film.

123 As well as the writer of the film; for a discussion on this see Monaghan (2007), pp. 98-100.
} 
possibility of alternative endings is illusory. ${ }^{124}$ Of course it did not end differently, because the writer did not wish it. ${ }^{125}$ Nor did James Green, when he considered what international law should do with the problem of cyberattacks, write a different ending to his piece, even though the sense of inevitability in legal problem-solution is allpervasive. Similarly, Nicholas Tsagourias writes how a 'non liquet has been avoided', suggesting 'it could have turned out differently' if the law had dictated otherwise. ${ }^{126}$

Yet the law does not speak for itself, and on the previous pages my aim was to show how its writers direct our focus in the text and thereby impact what we think the law is. ${ }^{127}$ '[T]he scholar him- or herself is an essential persona within [the] discursive plot', ${ }^{128}$ Paulina Starski writes, and she adds that to think of law as narrative "exposes [...] the concealment of the "I" and the misconception of the legal scholar as a purely objective observer'. ${ }^{129}$ This 'concealment of the I' also results from legal writing conventions, e.g. the frequent use of the passive voice ${ }^{130}$ and the use of the third person, e.g. 'the present author argues'. ${ }^{131}$ It imbues legal scholarship with a 'disembodied voice', the 'implicit claim that what we say in the text is objective, neutral, noncontingent, and wholly rational'. ${ }^{132}$ This is certainly true for the works discussed here. James Green writes how '[t]his chapter evaluates'; 'it' also 'sets out', 'considers' and 'argue[s] that', and in it, 'the present author shares' another scholar's "view that the Nicaragua "effective control" test is the more appropriate way of attributing cyber operations'. ${ }^{133}$ Similarly, Marco Roscini writes how '[r]emedies against cyber operations below the level of armed attack will [...] be analysed before turning to the role that the UN Security Council can play in relation to cyber operations' ${ }^{134}$ Moreover, like James Green, he refers to 'the present author's view' and how 'the present author has suggested elsewhere ....' ${ }^{135}$

The 'absence of an author ${ }^{136}$ occasioned by these phrases certainly makes it easier to 'forget the subject' whose writing and speaking 'thinks [and] produces law'. ${ }^{137}$ But to call this 'forgetting' and blame it on grammar is to gloss over a more fundamental point. The rather extreme 'effacement of any mediating

\footnotetext{
124 Troost and Greenfield refer to this sequence as resembling 'an author pondering the options for ending her tale'. Troost and Greenfield (2001), p. 192. See also supra n. 120.

125 See also supra n. 122.

${ }^{126}$ Similarly, Schlag (1991).

127 As an analogy from Woodmansee and Jaszi (1994), p. 1 ('texts do not [...] write themselves').

128 Starski (2018), p. 12.

129 Starski (2018), p. 13.

130 Wetlaufer (1990), p. 1568, fn. 60. On narrative perspectives in fiction, see Brillenburg Wurth and Rigney (2006), pp. 176-179.

131 Walková (2018), p. 100; Hu and Cao (2015), p. 15.

132 Wetlaufer (1990), pp. 1568, 1569; Starski (2018), p. 13; see also Walková (2018), p. 100 and Brooks (2006), pp. 27-28. For an analysis of US Supreme Court Opinions 'obfuscating [their] meaning', see Little (1998).

${ }^{133}$ Green (2015), p. 97, 113.

134 Roscini (2014), p. 44, emphasis added.

135 Roscini (2014), pp. 49, 67.

${ }^{136}$ Brooks (2006), p. 19; see also Baron and Epstein (1997), p. 151.

${ }^{137}$ Schlag (1991), pp. 1628, 1629.
} 
narrator ${ }^{138}$ achieved through a choice of grammar may indeed turn writers into 'non-participants of the communicative exchange', ${ }^{139}$ but more fundamentally, it is the writer who is effacing herself from the text. Jane Baron and Julia Epstein state how legal scholarship "also tells a "story" about its author-if only, in many articles, a story of invisibility'. ${ }^{140}$ Tellingly, in linguistic studies of academic writing both the use of the first person pronoun as well as the third ('the present author') are referred to as 'self-mentions indicat[ing] author presence'. ${ }^{141}$ The writer's invisibility is self-imposed, and in that sense as much proof of her presence as her overt textual appearance would be. James Green is as present in his text if he writes 'in this chapter it is argued' as he would have been had he only used the first person singular. ${ }^{142}$ With this in mind, to write a phrase such as in this chapter it is discussed how the jus ad bellum applies to cyberattacks' is no different from writing 'I think that the jus ad bellum doesn't apply to cyberattacks'. Both phrases signal the presence of a writer, orchestrating a particular experience of reading-ordering the law into its proper meaning ${ }^{143}$ - it is just that they do so in very different ways.

Acknowledgements Thanks to Renske Vos for her thoughtful and incisive comments on an earlier draft, and to the participants of the workshop on 'Narration and Aesthetics in Transnational Law and Politics' in Duisburg in February 2019, for their comments.

Open Access This article is distributed under the terms of the Creative Commons Attribution 4.0 International License (http://creativecommons.org/licenses/by/4.0/), which permits unrestricted use, distribution, and reproduction in any medium, provided you give appropriate credit to the original author(s) and the source, provide a link to the Creative Commons license, and indicate if changes were made.

\section{References}

Aldrich RW (1999) How do you know you are at war in the information age? Houst J Int Law 22:223-264

Amsterdam AG, Bruner J (2000) Minding the law. Harvard University Press, Cambridge

Aragay M (2003) Possessing Jane Austen: fidelity, authorship, and Patricia Rozema's Mansfield Park (1999). Lit Film Q 31:177-185

Bandes S (1996) Empathy, narrative, and victim impact statements. Univ Chic Law Rev 63:361-412

Barkham J (2001) Information warfare and international law on the use of force. N Y Univ J Int Law Politics 34:57-114

Baron JB (1994) Resistance to stories. South Calif Law Rev 67:255-286

Baron JB, Epstein J (1997) Is law narrative? Buffalo Law Rev 45:141-188

Benatar M (2014) Cyber warfare. Oxford Bibliographies. https://doi.org/10.1093/obo/9780199796 953-0087

Bentley E (1965) The life of the drama. Methuen \& Co LTD, London

Boer LJM (2015) 'Echoes of times past': on the paradoxical nature of Article 2(4). J Confl Secur Law 20:5-26

\footnotetext{
138 Brooks (2006), p. 18. A similar point is made by Schlag (1991), p. 1640.

139 Walková (2018), p. 100.

140 Baron and Epstein (1997), p. 151; Starski (2018), p. 13.

$141 \mathrm{Hu}$ and $\mathrm{Cao}$ (2015), p. 15.

142 Cf. Schlag (1991), p. 1649.

143 Supra n. 57.
} 
Boer LJM (2016) 'The greater part of jurisconsults': on consensus claims and their footnotes in legal scholarship. Leiden J Int Law 29:1021-1042

Boer LJM (2017) International law as we know it: cyberwar discourse and the construction of knowledge in international legal scholarship. Dissertation, Vrije Universiteit Amsterdam

Brillenburg Wurth K, Rigney A (eds) (2006) Het leven van teksten: een inleiding tot de literatuurwetenschap. Amsterdam University Press, Amsterdam

Brooks P (1992) Reading for the plot: design and intention in narrative. Harvard University Press, Cambridge

Brooks P (2006) Narrative transactions_-does the law need a narratology? Yale J Law Humanit 18:1-28

Brooks P, Gewirtz P (eds) (1996) Law's stories: narrative and rhetoric in the law. Yale University Press, New Haven

Bunton D (1999) The use of higher level metatext in Ph.D theses. Engl Specif Purp 18:41-56

Constable M (2014) Our word is our bond: how legal speech acts. Stanford University Press, Stanford

Cook NL (1994) Outside the tradition: literature as legal scholarship. Univ Cincinatti Law Rev 63:95-164

Cover RM (1983) The Supreme Court, 1982 term-foreword: nomos and narrative. Harv Law Rev 97:4-68

Delgado R (1989) Storytelling for oppositionists and others: a plea for narrative. Mich Law Rev $87: 2411-2441$

Foltz AC (2012) Stuxnet, Schmitt analysis, and the cyber 'use-of-force' debate. Jt Force Q 67:40-48

Forster EM (1990 [1927]) Aspects of the novel. Penguin, Harmondsworth

Gervais M (2012) Cyber attacks and the laws of war. Berkeley J Int Law 30:525-579

Green JA (2015) Cyber warfare: a multidisciplinary analysis. Routledge, Milton Park

Harrison Dinniss H (2014) Cyber warfare and the laws of war. Cambridge University Press, Cambridge

Henderson LM (2018) Courts, crisis, and contestation: democratic judicial decision-making in times of crisis. Dissertation, Vrije Universiteit Amsterdam

Herman D (ed) (2007) The Cambridge companion to narrative. Cambridge University Press, Cambridge

Hu G, Cao F (2015) Disciplinary and paradigmatic influences on interactional metadiscourse in research articles. Engl Specif Purp 39:12-25

Hyland K (2002) Options of identity in academic writing. ELT J 56:351-358

Hyland K (2004) Disciplinary discourses: social interactions in academic writing. The University of Michigan Press, Ann Arbor

Hyland K, Tse P (2004) Metadiscourse in academic writing: a reappraisal. Appl Linguist 25:156-177

Koskenniemi M (ed) (2000) Sources of international law. Ashgate, Dartmouth

Koskenniemi M (2005) From apology to utopia: the structure of international legal argument. Cambridge University Press, Cambridge

Lin HS (2010) Offensive cyber operations and the use of force. J Natl Secur Law Policy 4:63-86

Little LE (1998) Hiding with words: obfuscation, avoidance, and federal jurisdiction opinions. UCLA Law Rev 46:75-160

Monaghan D (2007) Reinventing Fanny Price: Patricia Rozema's thoroughly modern Mansfield Park. Mosaic: J Interd Study Lit 40:85-101

Moussa H (2004) Mansfield Park and film: an interview with Patricia Rozema. Lit Film Q 32:255-260

Paskey S (2014) The law is made of stories: erasing the false dichotomy between stories and legal rules. Legal Commun Rhetor JALWD 11:51-82

Porter Abbott H (2007) Story, plot and narration. In: Herman D (ed) The Cambridge companion to narrative. Cambridge University Press, Cambridge, pp 39-51

Rideout JC (2008) Storytelling, narrative rationality, and legal persuasion. J Legal Writ Inst 14:53-86

Rimmon-Kenan S (1983) Narrative fiction: contemporary poetics. Methuen, London

Roscini M (2014) Cyber operations and the use of force in international law. Oxford University Press, Oxford

Ryan M-L (2007) Toward a definition of narrative. In: Herman D (ed) The Cambridge companion to narrative. Cambridge University Press, Cambridge, pp 22-36

Schlag P (1991) The problem of the subject. Tex Law Rev 69:1627-1743

Schmitt MN (1999) Computer network attack and the use of force in international law: thoughts on a normative framework. Columb J Transnatl Law 37:885-938

Schmitt MN (ed) (2013) Tallinn manual on the international law applicable to cyber warfare. Cambridge University Press, Cambridge 
Silver DB (2002) Computer network attack as a use of force under Article 2(4) of the United Nations Charter. In: Schmitt MN, O’Donnell BT (eds) Computer network attack and international law. International Law Studies, vol 76, pp 73-98

Skouteris T (2008) The notion of progress in international law discourse. Dissertation, Universiteit Leiden

Starski P (2018) Fictional discourse in legal scholarship. Max Planck Institute for Comparative Public Law and International Law, on file with the author

Thompson G (2001) Interaction in academic writing: learning to argue with the reader. Appl Linguist 22:58-78

Toolan M (2007) Language. In: Herman D (ed) The Cambridge companion to narrative. Cambridge University Press, Cambridge, pp 231-244

Troost L, Greenfield S (2001) Jane Austen in Hollywood, 2nd edn. The University Press of Kentucky, Lexington

Tsagourias N (2015) The legal status of cyberspace. In: Tsagourias N, Buchan R (eds) Research handbook on international law and cyberspace. Edward Elgar Publishing, Cheltenham, pp 13-29

Walková M (2018) Author's self-representation in research articles by Anglophone and Slovak linguists. Discourse Interact 11:86-105

Werner WG, Boer LJM (2017) 'It could probably just as well be otherwise': imageries of cyberwar. In: Ambrus M, Rayfuse R, Werner W (eds) Risk and the regulation of uncertainty in international law. Oxford University Press, Oxford, pp 39-55

West R (1985) Jurisprudence as narrative: an aesthetic analysis of modern legal theory. N Y Univ Law Rev 60:145-211

Wetlaufer GB (1990) Rhetoric and its denial in legal discourse. Va Law Rev 76:1545-1597

White H (1987) The content of the form: narrative discourse and historical representation. The John Hopkins University Press, Baltimore

Wingfield TC (2000) The law of information conflict: national security law in cyberspace. Aegis Research Corporation, Falls Church

Woodmansee M, Jaszi P (eds) (1994) The construction of authorship: textual appropriation in law and literature. Duke University Press, Durham

Ziolkowski KC (2012) Ius ad bellum in cyberspace-some thoughts on the 'Schmitt-criteria' for use of force. In: Czosseck C, Ottis R, Ziolkowski K (eds) Proceedings of the 4th international conference on cyber conflict. NATO CCD COE Publications, Tallinn, pp 295-309

Publisher's Note Springer Nature remains neutral with regard to jurisdictional claims in published maps and institutional affiliations. 